\title{
Responsible Firm Behaviour in Political Markets: Judging the Ethicality of Corporate Political Activity in Weak Institutional Environments
}

\author{
Tahiru Azaaviele Liedong ${ }^{1}$
}

Received: 25 April 2019 / Accepted: 7 April 2020 / Published online: 21 April 2020

(c) The Author(s) 2020

\begin{abstract}
While support for corporate political activity (CPA) is well echoed in the literature, little has been done to empirically examine its ethicality. Moreover, existing ethical CPA frameworks assume normative and rational leanings that are insufficient to provide a comprehensive account of CPA ethicality. Utilizing the Ghanaian context, adopting a multiple case study design involving 28 Directors from 22 firms, and employing a grounded theory approach, I explore how the ethicality of CPA is determined in weak institutional environments. The findings reveal that business executives evaluate ethics at three levels (i.e. context, organizational and strategy) using three principles (i.e. utilitarianism, justice and institutions). Leveraging this knowledge, I present an eclectic framework that bridges the long-standing gap between normative ethical prescriptions and lived ethical realities. In doing so, I move away from abstraction to give "voice" to the actors involved in CPA. I also present a model that shows how the ethical judgement process is influenced by managerial intuition and interactive personal and organizational experiences. This article has important theoretical and practical implications for ethical business-government relations in developing countries.
\end{abstract}

Keywords Corporate political activity $\cdot$ Ethicality $\cdot$ Weak institutional environments · Ghana

\section{Introduction}

Politicians wield enormous influence in business environments (Weidenbaum 1980; Hillman and Hitt 1999). Their power to formulate policies and shape institutions has an inevitable effect on firm performance (Bonardi et al. 2006; Marsh 1998). This has led to a surge in corporate political activity (hereafter CPA), which refers to corporate efforts to influence government policy in favourable ways (Hillman et al. 2004). CPA research has mainly focused on topics such as the antecedents of political strategies (Hillman and Wan 2005; Liedong and Frynas 2017), the nature and types of political activity (Barron 2011; Decker 2011) and the outcomes of political activity (e.g. Hadani and Schuler 2013).

Though the current CPA research trajectory has unquestionable merits, it overlooks the ethicality of political activity. The interactions between politicians and firms have serious ethical implications that should not be ignored.

Tahiru Azaaviele Liedong

T.A.liedong@bath.ac.uk

1 School of Management, University of Bath, Claverton Down Road, Bath BA2 7AY, UK
According to Christensen (1997, p. 88), "there is an urgent need for study of the ethics of engaging in corporate political activity." CPA may improve firm performance (Hillman et al. 2004; Lux et al. 2011; Rajwani and Liedong 2015), but it may also create an unfair business environment that negatively affects consumer welfare and overall socio-economic development (Barker 2008; Mantere et al. 2009), especially in developing countries where it is largely unregulated (Liedong 2017). Despite these potential problems (Lawton et al. 2013), the ethicality of CPA has received little research attention (Neron 2016). A few frameworks for conducting ethical CPA have been proposed (e.g. Oberman 2004; Hamilton and Hoch 1997; Weber 1997), but they are conceptual, normative and prescriptive. There is therefore a lack of empirical research that gives "voice" to managers to understand their ethical experiences. Consequently, we have limited knowledge of the actual criteria and conditions that managers consider when judging the ethicality of their political engagements. This curtails our cognizance of the consonance or dissonance between conceptual normative ethical prescriptions and lived ethical realities.

The prevailing normative approach to the ethicality of $\mathrm{CPA}$, which is consistent with the dominant trajectory in 
the broader ethics literature (Rest 1986; Jones 1991) and is reflected in the prevalence of organizational codes of conduct (Weaver 2001), is particularly problematic because it implicitly assumes that individuals are rational actors who indulge in systematic and conscious reasoning to make sound decisions. Such a rationalist perspective treats ethical decision-making as a reflexive and deliberative process whereby actors can logically evaluate their actions based on established cognitive guidelines. However, this is not always true. Due to bounded rationality (Simon 1972), intuition plays a fundamental role in ethical judgements (Haidt 2001) and actually accounts for a wide range of unethical practices (De Cremer et al. 2011). This suggests the insufficiency of the rationalist and normative perspective for comprehensively understanding how ethical judgements are made (Barraquier 2011).

Moreover, existing ethical frameworks implicitly assume that CPA occurs in strong institutional environments. This is not surprising for two reasons. First, the frameworks are dominantly underpinned by the theories of utilitarianism, justice and rights (Bentham, 1789; Mill, 1863; Rawls 1971; Perelman 1963; Cavanaugh et al. 1981). These theories seem to be more relevant in well-functioning, developed and stable contexts. For instance, the rule of law is mostly illusive in developing countries. Second, and more importantly, CPA research was previously concentrated in Western contexts, which explains the orientation of existing ethical frameworks (e.g. Barker 2008; Grimaldi 1998; Neron 2016; Keffer and Hill 1997). However, CPA research has now expanded beyond earlier remits into Asia, Africa and other regions characterised by institutional fragility (e.g. Puck et al. 2013; Liedong et al. 2017; Nell et al. 2015; White et al. 2015; Wocke and Moodley 2015; Mbalyohere et al. 2017). In these developing contexts, normative ethical guidelines barely exist in the private sector, so how do firms judge ethicality?

To address the gaps above, this article addresses the overarching question-how do managers in institutionally weak environments determine the ethicality of corporate political activity? Specifically, it utilizes a behavioural approach to explore the political strategies used in Ghana and the interplay of factors that affect managers' ethical judgements of those strategies. A behavioural approach, as opposed to a rationalist perspective, is appropriate for understanding how managers make complex decisions amid divergent interacting factors (Barraquier 2011). The choice of Ghana as a suitable research context for exploring CPA ethicality is based on various reasons. First, Ghana is recognized as a beacon of democracy, hope, peace and stability in the Africa region and is popularly dubbed the "gateway to West Africa" (Debrah 2002; Amankwah-Amoah et al. 2018). Hence, the sanity of her CPA is critical to the wider development of ethical business-government relations in the sub-region. Second, business-government relations positively affect Ghana's socio-economic development through their impact on public-private partnerships, policy formulation and capacity building (Amankwah-Amoah et al. 2018). However, Ghana suffers institutional weaknesses (Acquaah 2007; Liedong et al. 2017), which gives rise to systemic corruption (van den Bersselaar and Decker 2011; Liedong and Frynas 2017) and poor corporate governance practices within politically active firms (Liedong and Rajwani 2018). These problems curtail or negate the promise of CPA and call for ethical business-government relations, which can be achieved by firstly understanding how managers evaluate the ethicality of their political engagements. Lessons from Ghana, an icon of democracy in Africa, can be transferred to other institutionally similar countries within the region.

This article makes three key contributions. First, it sheds light on the political strategies used by firms in weak institutional contexts, and adds to the variety of political tactics already documented in the literature. Extant CPA strategies are mostly Western oriented (e.g. Hillman and Hitt 1999; Keim and Zeithaml 1986; Keim and Zeithaml 1981) and thus have limited applicability in developing countries where the institution frameworks do not support their deployment (Rajwani and Liedong 2015). Currently, managerial political ties are portrayed as the major political strategies used in developing countries (e.g. Li et al. 2008; Peng and Luo 2000; White et al. 2015), but this is half the story. I uncover three strategies, namely financial, relational and logistic strategies that are leveraged on and facilitated by weak regulatory conditions.

Second, I contribute to the business ethics literature by presenting an eclectic framework and a process model to capture how managers judge the ethicality of political activity in weak institutional environments. Through the framework, I bridge the long-standing gap between normative prescriptions and actual experiences, perceptions and evaluations of CPA ethicality. In doing so, I move away from abstraction, give "voice" to CPA actors and extend theory (e.g. Gao 2008; Oberman 2004) by adding two new dimensions of ethical analysis-namely context and organizational- to the unidimensional approach adopted in existing ethical frameworks. The eclectic framework herein holistically shows how the ethicality of political activity is judged at three levels - context (where CPA is done), organizational (who does CPA), and strategy (how CPA is done), with each level entailing an array of pertinent issues and criteria informed by three ethical principles-utilitarianism, justice and institutions. Noteworthy is the institutions principle, which is arguably inconspicuous in Western-based ethics frameworks (e.g. Keffer and Hill 1997; Oberman 2004) but nevertheless echoes the institutional failures in developing countries and how ethical judgements consider institutional strengthening as an important criterion. This principle recognizes how weak institutions allow "privileged" firms to 
be egoistic without repercussions, exploitative without consequences and usurping without constraints. Through the process model, I open the "blackbox" to show how managerial intuition and experiences underpin ethical judgements in weak institutional contexts.

Finally, this article provides empirical evidence from a developing context to corroborate the insufficiency of normative or rationalist ethics (Barraquier 2011; De Cremer et al. 2011) and the weaknesses of utilitarian ethics (Gao 2008). Optimizing satisfactions for the greatest number, which is the cardinal tenet of utilitarianism (Audi 2007; Cavanaugh et al. 1981), is prone to subjective interpretations. My findings show that managers find it difficult to define "public interests" or weigh the cost and benefits of their actions for the "public." Consequently, they replace "public interests" with "affiliated group interests", regardless of how narrow or parochial the latter may be. My findings also reveal that the difficulty of determining "the greatest happiness of the greatest number" (Post et al. 1999) is accentuated by poor institutional conditions that render efficient cost-benefit analyses difficult, giving way to intuitive and convenient shortcuts that favour powerful and "loud" interests. In this sense, utilitarianism in weak institutional environments seems to dwell more on "voice-power" than "costbenefits". These findings demonstrate bounded rationality, weakness of rationalist ethics and the prevalence of intuition in CPA ethicality.

In the next section, I review literature on CPA, the arguments for and against CPA, and the theoretical frameworks of CPA ethicality. After, I describe the research methods used to collect and analyse the data. Subsequently, I present and discuss the findings. I conclude with a note on practical implications and an outline of future research directions.

\section{Corporate Political Activity}

Governments have the mandate and power to enact rules that shape market institutions and business environments (North 1990). Firms are therefore highly dependent on the policies and actions of politicians for conducive investment climates (Lester et al. 2008; Hillman et al. 2009). This is particularly true in developing countries where governments direct the allocation of critical resources (Peng and Luo 2000; Guo et al. 2014) and wield significant authority and power amid weak checks and balances to arbitrarily formulate or apply regulations (Henisz 2004; Liedong and Frynas 2017; White et al. 2015). This dependency motivates firms to create linkages to politicians or deploy actions and efforts to influence government policy in their favour (Getz 1997; Hillman et al. 2004). The phenomenon of corporations attempting to make their preferences reflected in public policy or seeking to benefit from "preferential" government treatment is generally referred to as CPA.

Research on CPA has touched on various themes, including the rationale, antecedents and performance implications of political embeddedness (Lux et al. 2011; Rajwani and Liedong 2015). Among the firm-level antecedents of CPA, firm size appears more prominent. Numerous studies show that large firms are more politically active and are also more likely to act alone in political markets (e.g. Hillman et al. 2004; Weymouth 2012; Wocke and Moodley 2015). This is because they have the resources to engage politicians and governments (Hillman and Hitt 1999). The influence of firm size in CPA, coupled with evidence that firms are more likely to do CPA in weak institutional environments where economic freedom and regulatory quality are low (White et al. 2015; Wan and Hillman 2006), raise ethical concerns regarding inclusive policy making and equitable distribution of public goods in developing countries. Large firms could hijack and dominate policy processes, to the detriment of smaller firms.

CPA is executed through political strategies. The most popular of them are the financial, information and constituency building strategies (Hillman and Hitt 1999). These strategies, respectively, correspond with the three goods exchanged in political markets-i.e. money, information and votes (Wan and Hillman 2006; Bonardi et al. 2005). While I acknowledge the usefulness of these strategies, I also note that they do not have universal application. For instance, the information strategy is rarely used in developing countries due to lack of supporting institutional structures (Liedong and Frynas 2017).

Consequently, most CPA studies in developing markets tend to focus on personal or social connections between managers and politicians (e.g. Guo et al. 2014; Li and Zhang 2007; Li et al. 2008; Peng and Luo 2000; White et al. 2015). These connections, collectively called relational strategies (Rajwani and Liedong 2015), are leveraged on the cultural conditions (i.e. high context and collective) and economic systems (i.e. relationship based) prevailing in developing countries. However, the narrow focus on social relationships tells a partial story because firms could use other political strategies. For instance, Chinese firms are increasingly deploying corporate social responsibility (CSR) as a political tool to gain access to the polity (Wang and Qian 2011; Zhao 2012), which is possible because these firms are able to exploit their contributions to society in a country where the government is keen to advance socio-economic development.

There is a consensus that CPA increases competitive advantage and improves firm performance (see Hillman et al. 2004; Lux et al. 2011; Rajwani and Liedong 2015 for reviews of the literature). Nevertheless, other studies have documented how political activity destroys shareholder 
value (e.g. Bliss and Gul 2012; Carretta et al. 2012; Hadani and Schuler 2013). The focus on CPA instrumentality has provided concrete facts about the benefits and costs of political embeddedness, but the equivocal value of CPA spurs a debate about whether firms should even be allowed to influence public policy.

\section{Corporate Involvement in Politics: Yes or No?}

According to Clawson et al. (1998, p. 21), CPA is like "a class struggle just as surely as are strikes and mass mobilizations". By this depiction, CPA aims to protect and safeguard corporate interests (Leong et al. 2013), but whether this is right or wrong is open to controversial interpretations. On the one hand, the justification of corporate involvement in politics is premised on the concept of corporate citizenship (Logsdon 2004; Matten and Crane 2005; Wood and Logsdon 2008) which treats firms as citizens that are permitted, if not required, to participate in political processes and contribute to social welfare by filling regulatory gaps and sponsoring or endorsing "best political candidates" (Alzola 2013; Scherer et al. 2013). Some scholars argue that firms have the right to speak on public issues and protect their interests (Ostas 2007; Lascelles 2005). The right to lobby or petition the government is defined as the right to free speech (Redish 1982; Allard 2008). In addition, firms may have knowledge that is useful for policy making (Hamilton and Hoch 1997). By sharing this knowledge, they help politicians to understand issues from different perspectives and enable them to formulate informed policies that benefit society while reducing any unintended consequences (Hillman and Hitt 1999; Lawton et al. 2014; Christensen et al. 2017). Information sharing is particularly important because "policymakers are often imperfectly informed about the consequences of various policy alternatives for the wealth and well-being of their constituencies" (Lohmann 1995, p. 267). Firms may also need to represent their stakeholders in policy processes (Leong et al. 2013), in which case CPA is considered to be a socially responsible activity that is not only permissible, but also obligatory (Neron 2016).

On the other hand, the concept of corporate citizenship has been questioned and disputed to oppose corporate involvement in policy making. Firms may be described as citizens, but in the real sense, they are only "like citizens in the societal roles they play" (Moon et al. 2005, p. 431). Unlike individual citizens, firms cannot vote or run for public office (Alzola 2013; Neron and Norman 2008). Hence, it is deemed undemocratic and illegitimate for non-elected managers to act like State institutions or influence public policy (Scherer et al. 2013). Allowing firms to influence policy is unfair because corporate citizens (versus individual citizens) have larger budgets to dominate policy processes and impoverish the quality of democratic systems (Alzola 2013; Dworkin 2000).

When firms hijack democratic processes, the costs and benefits of public policy are unequally distributed (Grimaldi 1998). This is because firms are often depicted as self-interested entities (Oberman 2004) seeking to influence policy in their favour, regardless of the consequences for wider society (Gao 2008). In this sense, their legitimacy to influence public policy is questionable (Scherer et al. 2013). Even more damning is the problem of unequal economic and political powers. Without economic equality, the preferences of a few "deep-pocketers" become representative of the collective will of citizens and the business community (Barnett 2013). Overall, the answer to the question of whether firms should be allowed to participate in policy making is not simple or straightforward. The most convenient answer is, it depends, but on what?

\section{What Makes CPA Ethical?}

Considering the arguments for and against firms' involvement in policy making, does a middle ground exist? Surely, the need for CPA has been acknowledged, but the major problem is the negative externality it generates. Some scholars have therefore posited ethical frameworks that prescribe what would make CPA ethical, fair and beneficial to the majority (e.g. Gao 2008; Oberman 2004; Keffer and Hill 1997). Before exploring these frameworks (see summary in Table 1), I would like to firstly acknowledge their theoretical foundations.

Ethical requirements and principles for CPA are based on the theories of utilitarianism (Bentham, 1789), rights (Cavanaugh et al. 1981) and justice (Rawls 1971). Utilitarianism, a branch of consequentialism that focuses on outcomes (Morrison et al. 2018), views ethical acts as the ones that produce the greatest good for the greatest number (Audi 2007; Mill, 1863). The theory of justice requires ethical acts to be fair and impartial. It holds that there should be distributive justice whereby people are treated similarly when they are similar and differently, if different, in proportion to their differences (Perelman 1963). It also holds that people should be compensated for harm or wrong done to them (Cavanaugh et al. 1981). In developing countries where poverty and inequity is often rife, national policies and corporate actions are expected to be utilitarian and fair to create broad-based prosperity for the greatest number while indemnifying affected persons for injury and loss (Beddewela and Fairbrass 2016; Hennchen 2015). This expectation might also exist in the ethical analysis of CPA, but the key challenge of utilitarianism is the difficulty of measuring cost and benefits (Post et al. 1999; Gao 2008). The theory of rights, which views ethical acts as ones that respect fundamental rights (Cavanaugh et al. 1981), has a weaker relevance to 
developing countries where the rule of law is weak (Henisz and Zelner 2010; White et al. 2015).

Leveraging the above theories, ethical CPA guidelines are centred on at least three issues, namely: (1) the goals or intentions of CPA; (2) the means used to achieve the goals of CPA; and (3) the consequences of CPA (see Table 1 for a summary). Oberman (2004) applied Mitnick's (1993) "political contestability" to propose that the ethics of political actions should be evaluated on three criteria: access, legitimacy and influence/exploitation. He argued that CPA is ethical if it does not violate or restrict the contestability of politics. Similarly, Gao (2008) and Tian et al. (2008) proposed that CPA that pursues appropriate goals (intentions), uses appropriate means and processes, and results in appropriate consequences is absolutely ethical. While Weber (1997) echoed similar views, he argues that ethical standards for CPA should be focused on providing practical guidelines regarding which behaviours should be avoided, even if legal. Hamilton and Hoch (1997) contend that while CPA is a "self-interest" activity, it is not necessarily wrong if all sides present their cases and decisions are made to maximize benefits while respecting rights and ensuring just distribution of costs and benefits. However, they note that CPA becomes unethical if the objective is to benefit at the expense of the general good. Accordingly, they proposed eight standards of business lobbying. In 2002, the Woodstock Theological Centre at Georgetown University also developed and published seven lobbying principles (Woodstock Principles).

Other frameworks have also outlined specific criteria for ethical CPA. For instance, Keffer and Hill (1997) classified lobbying into three categories—good, problem and badbased on communitarianism and legality. They provide itemized tactics for each category. In the same vein, Leong et al. (2013) applied utilitarian logics to derive eight recommendations for managing the risk of political donations. Further, Bauer (2014) presented a multidimensional responsible lobbying model based on three pillars: (1) alignment of CSR and lobbing; (2) consideration of stakeholder needs and interests; and (3) alignment of objectives and values with society.

Overall, existing ethical frameworks provide a useful guide for practicing ethical CPA. However, they are mostly theoretical and normative and hence could be detached from reality because actual managerial perceptions of CPA ethicality may differ. The major problem with the existing normative approach is that it makes an implicit assumption that individuals are rational, deliberative and logical in their ethical evaluation (Rest 1986; Jones 1991; Weaver 2001). In reality, that is not always true. Research has shown how intuition and automatic processes shape ethical judgements (Haidt 2001; Bargh and Chartrand 1999). In weak institutional environments, normative ethics barely exist in the 
private sector. This raises a question about whether intuition drives ethical judgements. Additionally, the existing ethical frameworks for CPA are largely Western oriented, and hence could be inapplicable in developing contexts. A scrutiny of the most cited normative ethical models (Trevino 1986; Hunt and Vitell 1986; Kelley and Elm 2003) reveals a limited focus on context. Essentially, the broader macro institutional environment is overlooked, despite its stronger influence on how individuals make decisions and how organizations behave. In this article, I explore how ethical judgements are made, the micro and macro issues considered and the process. The next section describes the methodology I used.

\section{Methods}

\section{Research Context}

This study is set in Ghana, a democratic country in West Africa. While CPA exists in Ghana, there is little research on the practice. So far, only a few studies have empirically studied the interactions between businesses and politicians in Ghana (Liedong and Rajwani 2018; Liedong and Frynas 2017; Liedong et al. 2017). These studies focus on managerial political ties-i.e. social connections or relationships between managers and the polity (Acquaah 2007, 2012). As Ghana is a relationship-based economy, just as China and other Asian countries are (Park and Luo 2001; Xin and Pearce 1996), personal connections dominate CPA. However, firms could be using other political strategies. It costs a minimum of US $\$ 85,000$ to contest parliamentary elections (CDD Ghana 2018) in Ghana, hence money plays a crucial role in politics, but where does the money come from?

Ghanaian political parties generate their funds from membership dues, dedicated fundraising durbars, bank loans, and nomination fees, but these sources are woefully inadequate. Consequently, they are unable to support their candidates, leaving them to rely on personal income (CDD Ghana 2018). This creates opportunities for interests (including firms) to capture the political process through "plutocratic funding" (Arthur 2017; Bagbin and Ahenkan 2017), giving rise to corruption (Liedong 2017; CDD Ghana 2018). A former Minister of State remarked "check all the corruption-related cases...it is linked to campaign financing. It is because our hands are tied" (Mordy 2018).

Political party financing in Ghana is regulated by the Political Parties Act (2000), but the law has loopholes. There are no provisions limiting donations, neither are there requirements for disclosing donor identities. Moreover, the law has no limits on how much can be spent or how the funds should be used. Consequently, even the Electoral Commission (the regulatory body) cannot track how much money political parties raise, from whom, and how funds are used (Magolowondo et al. 2012). It is fair to say that except for a ban on foreign donations, party financing in Ghana is unregulated. Further, the Electoral Commission lacks the capacity to enforce the Political Parties Act, resulting in widespread breaches and violations (Arthur 2017; Ayee et al. 2008).

Besides weak political financing rules, Ghana lacks formal channels for business-government relations and policy consultations (Liedong and Frynas 2017). There are no structures specifying the process and requirements for businesses to participate in policy making. This, coupled with a generally weak corporate governance culture in the country (Tsamenyi et al. 2007; World Bank 2005), creates not only a breeding environment for ethically suspect CPA but also offers an interesting context to explore how managers make ethical judgements about CPA.

\section{Data and Analysis}

I employed a multiple case study design to collect data using in-depth semi-structured interviews (Yin 2003). A qualitative and inductive approach is best suited for this study, as it allows for a deeper probing of participants' rationales, practices and lived experiences (Morse and Richards 2002). As Reinecke et al. (2016, p. xiv) note, it "offers a more contextual understanding of business ethics from the vantage point of the complex and pluralistic reality of the actors themselves... and views business ethics through the lens of the participants' perceptions of his or her experiences rather than through the lens of abstract categories and concepts imposed by researchers" I developed the sample in two stages. First, to ensure that the sample is representative, I purposely selected 50 small firms, 50 medium firms and 50 large firms from the membership directory of Association of Ghana Industries (AGI) and BusinessGhana. These firms were purposely selected because in my previous research, I found them to engage in corporate political activity. I verified this status quo before data collection. Based on OECD criteria, I defined a small firm as one with 10-49 employees, a medium firm as one with 50-249 employees and a large firm as one with 250 or more employees. Second, within each of these three strata, I randomly selected 10 firms while ensuring industry diversity.

Calls were made and emails were sent to request participation. After several follow ups, 28 Directors and Senior Managers from 22 local firms were interviewed. The final sample comprised participants from seven large, eight medium and seven small firms (see sample characteristics in Table 2). Throughout, I preferred respondents whose work or positions entrusted in them responsibilities for managing external, public or government affairs. Due to the sensitive nature of CPA in Ghana, the respondents were assured of anonymity and confidentiality of the data. Consistent with 
Table 2 Sample characteristics

\begin{tabular}{|c|c|c|c|c|}
\hline Firm & Firm size $^{\mathrm{a}}$ & Industry & Interviewee & Interviewee position \\
\hline A & Large & Mining & A1 & Manager, External Relations \\
\hline \multirow[t]{2}{*}{$\mathrm{B}$} & \multirow[t]{2}{*}{ Large } & \multirow[t]{2}{*}{ Oil \& Gas } & B1 & Manager, Business Analysis \\
\hline & & & B2 & General Manager, Government Affairs \\
\hline $\mathrm{C}$ & Medium & Pharmaceutical & $\mathrm{C} 1$ & Marketing Manager \\
\hline $\mathrm{D}$ & Medium & Automobile & DI & Director, Public Relations \\
\hline $\mathrm{E}$ & Large & Oil \& Gas & E1 & Senior Manager, Policy, Regulatory \& Public Affairs \\
\hline \multirow[t]{2}{*}{$\mathrm{F}$} & \multirow[t]{2}{*}{ Small } & \multirow[t]{2}{*}{ Textiles } & $\mathrm{F} 1$ & Chief Financial Officer \\
\hline & & & $\mathrm{F} 2$ & Manager, Public Affairs \\
\hline $\mathrm{G}$ & Medium & Transport & GI & Managing Director \\
\hline $\mathrm{H}$ & Small & Food \& Beverage & HI & Manager, Operations \& Communications \\
\hline I & Large & Telecommunications & I1 & Manager, Regulatory \& External Affairs \\
\hline $\mathrm{J}$ & Small & Transport & $\mathrm{J} 1$ & Chief Executive Officer \\
\hline $\mathrm{K}$ & Medium & Construction & KI & Deputy Managing Director \\
\hline \multirow[t]{2}{*}{$\mathrm{L}$} & \multirow[t]{2}{*}{ Large } & \multirow[t]{2}{*}{ Telecommunications } & L1 & Manager, Corporate Communications \\
\hline & & & $\mathrm{L} 2$ & Operations Manager \\
\hline M & Medium & Food \& Beverage & M1 & Chief Executive Officer \\
\hline \multirow[t]{2}{*}{$\mathrm{N}$} & \multirow[t]{2}{*}{ Small } & \multirow[t]{2}{*}{ Publishing \& Stationery } & $\mathrm{N} 1$ & Deputy Managing Director \\
\hline & & & $\mathrm{N} 2$ & General Manager \\
\hline $\mathrm{O}$ & Medium & Hotels \& Hospitality & $\mathrm{O} 1$ & Chief Executive Officer \\
\hline \multirow[t]{2}{*}{$\mathrm{P}$} & \multirow[t]{2}{*}{ Large } & \multirow[t]{2}{*}{ Construction } & $\mathrm{P} 1$ & Managing Director \\
\hline & & & $\mathrm{P} 2$ & Operations Manager \\
\hline Q & Large & Media & Q1 & Senior Manager, Corporate Affairs \\
\hline $\mathrm{R}$ & Medium & Waste Management & $\mathrm{R} 1$ & Deputy Managing Director \\
\hline $\mathrm{S}$ & Small & Construction & $\mathrm{S} 1$ & Director of Operations \\
\hline $\mathrm{T}$ & Small & Publishing \& Stationery & $\mathrm{T} 1$ & Managing Director \\
\hline \multirow[t]{2}{*}{$\mathrm{U}$} & \multirow[t]{2}{*}{ Small } & \multirow[t]{2}{*}{ Media } & U1 & Director of Public Relations \\
\hline & & & $\mathrm{U} 2$ & Business Operations Manager \\
\hline V & Medium & Manufacturing, Plastics & V1 & Managing Director \\
\hline
\end{tabular}

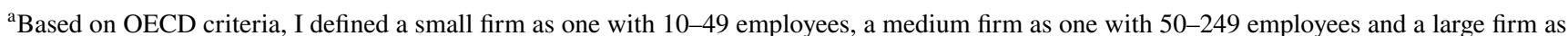
one with 250 or more employees

standard practice (Amaeshi et al. 2016), the pilot-tested questions were sent to the respondents to prepare ahead of the interviews. The interviews, which lasted between $45 \mathrm{~min}$ and $1 \mathrm{~h}$, were recorded and transcribed. Following Eisenhardt (1989), I triangulated the interview data with secondary data, specifically using news articles to corroborate and validate the primary evidence I gathered from managers about the political strategies firms use.

Employing grounded theory (Strauss and Corbin 1998) and using previously validated approaches for inductive theory development (e.g. Yin 2003), I analysed the data in three steps. Following the principles of grounded theory, I started the analysis soon after collecting the first bit of data (Corbin and Strauss 1990). The early insights directed the subsequent interviews, allowing me to adhere to the standardized interview protocol while adjusting for procedural and design flexibility to help discover new concepts (Gioia et al. 2013).
First, I open-coded and analysed the transcripts (within and cross-case) to develop first-order descriptive concepts. In doing this, I was able to construct a story for each of the cases. Second, I did axial coding to develop second-order themes by identifying linkages between the first-order codes. This process involved iterations between theory and data (Gioia et al. 2013) to find informed and grounded connections between the first-order codes (Langley 1999). In the final selective coding stage, I created aggregate dimensions by integrating the second-order themes to develop theory of CPA ethicality. This final stage led to the development of grand constructs to explain how managers in Ghana make ethical judgements (see data structure in Fig. 1). 


\section{Open Coding: \\ First-Order Codes -Concepts

$\begin{array}{cc}\text { Axial Coding } & \text { Selective Coding: } \\ \text { Second-Order Codes - Categories } & \text { Aggregated Dimensions }\end{array}$

- Using kinship/family ties to politicians

- Using school/alumni associations

- Using friendships with politicians

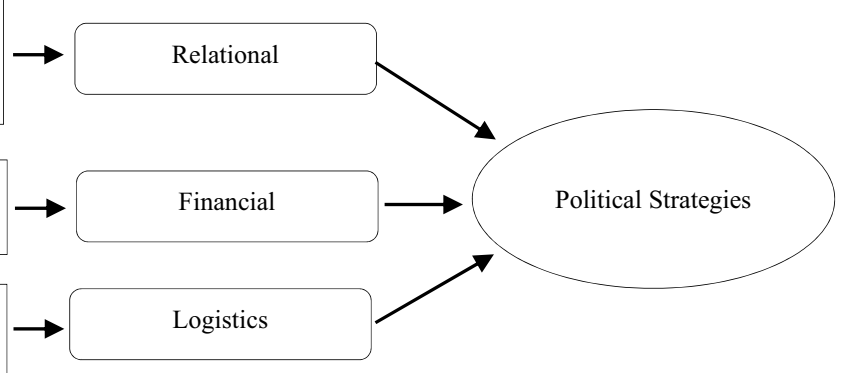

- Regulation of CPA in the country

- Legitimacy of CPA in the country

- $\quad$ CPA and impoverishment in the country

- The size of the firm that is doing CPA

- The type of firm that is doing CPA

\section{Purpose of $\mathrm{CPA}$}

- Win business/contracts

- Overcome institutional weaknesses/problems

- Protect industry interests

\section{Mechanisms of CPA}

- Gaining access to politicians and political processes (access)

- Using politicians to restrict/disadvantage competitors (capture)

\section{Outcomes of $\mathrm{CPA}$}

- Impact on affiliated groups

- Impact on national/public institutions

$$
\begin{aligned}
& \text { - Beneficial or useful to the majority } \\
& \text { - Beneficial or useful to the poor masses }
\end{aligned}
$$
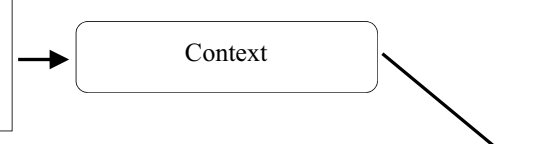

- Equal access for other interest groups

- Fair treatment of other interest groups

- National/public institutional strengthening

- Quality of democratic institutions and processes

- Policy quality

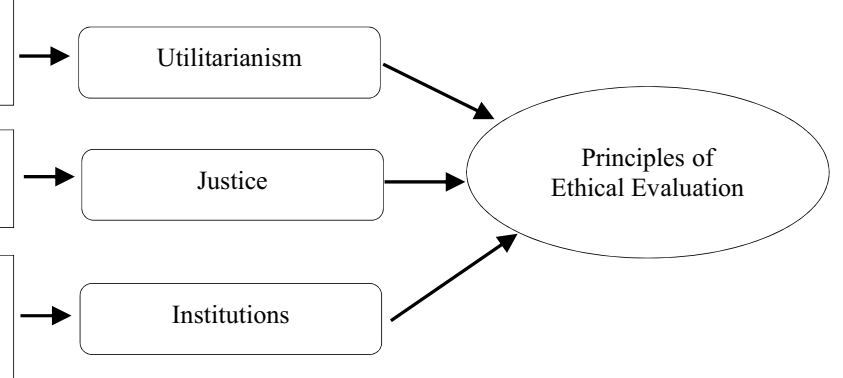

Fig. 1 Data structure

\section{Findings}

\section{CPA Strategies}

The data show that firms in Ghana use three strategies-relational, logistic and financial strategies-to wield influence and relevance in the political arena. The relational strategy involves the use of social connections to politicians. These social connections are developed in three ways. First, managers who are related to politicians, whether in a nuclear or extended family sense, leverage their kinship to gain access to the polity. As Ghana has a collective national culture (Ayentimi et al. 2018), kinship is the most valuable asset for deploying a relational strategy. Politicians are more willing 
to extend favours to their own people, and this is not only because society expects them to do so, but also because they can trust their own to support or protect them in the future. Moreover, much of the rent or favours that politicians give to firms do not go through due processes, hence dealing with relatives keeps transactions within a small close-knit circle and protects the politician from leakages, betrayals and reprisals while guaranteeing economic prosperity for the family. With a common understanding that the success of a politician is tantamount to the success of the politician's collective family, politicians trust their relatives to use the opportunity to create a "better tomorrow". In this sense, the effectiveness of kinship is underpinned by politicians' personal gain.

When you are a relative to a politician and you own a business, you get special privileges no other company may get. You will find yourself at the heart of favourable political decisions (E1)

The other ways of developing social capital are through school connections, alumni associations and friendship. Managers whose former school mates become politicians can use their common affiliations to establish political connections. Some managers are also able to befriend politicians, although this channel mainly works for the managers of large and visible firms. Corporate visibility increases corporate appeal and managerial self-worth (Fuller et al. 2006), which makes it easier to befriend politicians (Liedong et al. 2017). For the managers of small firms, it is easier to befriend politicians before they hold political office. Otherwise, it becomes difficult, if not impossible, to reach politicians when they are incumbents.

It is better to know them [politicians] before they win power because when they have power, they cater more to those they already know. Newcomers are treated like opportunists (T1)

The data show that the relational strategy is widely used in Ghana. CPA research in developing countries mainly show that firms try to influence politicians using social capital, which they develop through informal personal connections (Peng and Luo 2000; Li et al. 2008; Guo et al. 2014) or formal directorships and shareholding (Khwaja and Mian 2005; Johnson and Mitton 2003; Faccio 2006). Indeed, previous studies have examined the former within the Ghanaian context (Acquaah 2007; Liedong et al. 2017). The findings herein are consistent with these studies.

The logistics strategy entails firms creating access to politicians by providing material and logistical support during campaigns. Due to limited and ineffective sources of financing for political parties in Ghana (Bagbin and Ahenkan 2017; Fobih 2011), politicians rely on personal income to run their campaigns (CDD Ghana 2018). Some firms invest in these campaigns by supplying materials and equipment such as transportation, branded apparel (cloths, shirts, hats), and refreshments (water, snacks, meals). The viability of this strategy depends, to a large extent, on whether a firm's line of business is related to the logistics politicians need. For instance, a textile company could easily print campaign banners and branded clothing for politicians. A hotel could provide free lodging for politicians and their team. A fleet company could provide free transportation services for politicians to canvass the country. When firms do this, they take the burden off politicians, and position themselves for preferential treatment if the politicians win elections.

Political parties need to provide refreshments at their rally grounds and politicians need to do same at their homes and offices for their visiting supporters. We provide bottled water and soft drinks, and the politicians are grateful and remember us in future (M1)

Essentially, the logistics strategy directly provides equipment and services that politicians would otherwise pay for. The alternative to this strategy is to give money to politicians and political parties to procure their own logistics. The financial strategy, as the name suggests, involves firms making financial donations and contributions to politicians and political parties. Senior managers and board members directly send financial sponsorship to parties and candidates, with the expectation of reciprocation in the future. I found that due to the lack of transparency in political party financing in Ghana (Bagbin and Ahenkan 2017), firms hedge against risks by donating to the two dominant political parties that have shared the spoils of power since 1992 (i.e. NDC and NPP). This way, it would not matter which party wins; the firms will still be in good standing. When you play all the parties or just the major ones, you don't lose (Q1). The financial strategy is similar to political action committee (PAC) contributions that are replete in western CPA literature (e.g. Cooper et al. 2010; Dean et al. 1998; Hadani and Schuler 2013; Milyo et al. 2000; Schuler et al. 2002), but different in the sense that it is largely unregulated and opaque.

Secondary evidence suggests that the logistics and financial strategies are also prevalent in Ghana. For instance, the Ghana Private Transport Union (GPRTU) - an umbrella group or trade union of private transport owners in Ghanaprovided free transportation for NDC (political party) members and supporters to travel to rallies and polling stations during the 2004 elections (Arthur 2017; Fobih 2008). There is also evidence of businesspersons sponsoring political parties in Ghana for favours (Houlton 2012), a phenomenon labelled "pay to play" (Atta Mills 2018). It underpins the rampant corruption in the country. A former Minister of State, whose tenure was marred by corruption scandals, noted that: 
People who have given you T-shirts and money and all kinds of things and now you are dealing with them... there were pressures from within and without because you are cutting off the source of funding...check all the corruption-related cases, from BOST to whatever, it is linked to campaign financing. There is always a financier there (Mordy 2018).

I note that some of the above strategies have not been documented in the emerging market CPA literature. Two reasons might explain why. First, the majority of emerging market CPA studies tend to focus on managerial political ties (e.g. Sheng et al. 2011; White et al. 2015), but these ties are like end-form strategies that are founded on other intermediate strategies. The relational, logistics and financial strategies offer conduits for establishing political ties. In this sense, political ties are higher-order strategies propped up by lowerorder logistics and financial strategies.

You cannot just walk up and befriend a politician.

Something has to give to get the friendship going.

Money or material support are sure starting points

(A1)

Second, the absence of a strong regulatory framework to legitimize and make political party financing transparent (Arthur 2017; Ayee et al. 2008) has caused firms to be highly discreet about their financial and logistic support for politicians. Being explicit is unwise, as it could lead to political witch hunt from opposition parties and politicians. This typically takes the form of sabotage, discrimination and revocation of public contracts (Arthur 2017). In Brazil where there is a law that regulates campaign financing, researchers have been able to examine contribution data (Claessens et al. 2008). Unfortunately, this kind of data do not exist in Ghana. Even Ghana's Electoral Commission (i.e. the regulator) may not have this data. Overall, I found strategies that are largely undocumented in the literature, partly because Ghana's institutional conditions make them inconspicuous and partly because they are inaccessible to the dominant quantitative approaches utilized in the CPA literature. I also found overwhelming evidence that CPA is perceived as unethical. "A lot of the interactions between companies and politicians are shady" (F1). Taking cue from this, I further explored how managers judge the ethicality of CPA.

\section{Ethical Evaluation}

The data revealed that there are three levels at which the ethicality of political activity is analysed-context, organizational and strategy. At each level, respondents applied utilitarian, justice and institutions principles to make their judgements using established criteria. These criteria and the ethical principles are informed and shaped by interactive personal and organizational experiences (e.g. CPA performance, CPA outcomes), which subsequently develop and strengthen managers' intuition of CPA.

\section{Context Level}

Here, ethical judgements consider the general environment within which CPA is done. I aggregated managers' views into three perspectives-legal, legitimacy and impoverishment. Within the legal perspective, respondents indicated that when there are laws governing political strategies, they perceive CPA to be ethical. This perspective equates legality with ethicality. If political strategies are unregulated, they are judged to be unethical. Because Ghana does not have strong CPA regulatory structures, the respondents argued that the relational, logistics and financial strategies are liable to abuse whereby sponsors can usurp power and become dictatorial to undermine democratic processes, harm the majority and treat others unfairly.

If the law does not clearly specify the terms of engagement, then there is an ethical problem. Regulation makes things clear and protects everyone (B2)

Despite this view, managers feel pressured to do CPA to gain or sustain competitive advantage. Though they could voluntarily disengage from the polity, as suggested by Weber (1997), doing so will disadvantage them if other firms continue to engage with politicians (Grimaldi 1998). This is similar to the disadvantage that firms face when they are loners in the fight against corruption (Liedong 2017; Luiz and Stewart 2014), but it more importantly shows how rationality does not prevail against norms and bandwagons regardless of the logical and cognitive views held by actors.

Regardless of how bad we think it is, we cannot withdraw while our competitors are doing politics. Not good for our business. We have no choice but to also do politics (L1)

In contrast, the legitimacy perspective believes that if the law does not clearly regulate or prohibit CPA, then there are no ethical concerns. For this perspective, political strategies that are common and widely used are considered legitimate, even if they straddle "grey zones" in terms of the law. What matters is the "normality" of the political strategies. Normality in this instance refers to the prevalence of the strategies, and the extent to which they are accepted in business and political circles. Respondents argued that if other firms are doing CPA, there are no ethical problems with their firms also doing it, indicating how isomorphic pressures to do CPA may cause managers to absolve themselves of ethical blame. The views from the legitimacy perspective are consistent with Christensen's (1997, p. 85) argument that the legitimacy of CPA "depends on the expectations of 
society—its political culture." It also corroborates Hilliard's (2002) assertion that people in Africa justify widespread practices to be ethical. Indeed, it can be argued that CPA is part of Ghana's political culture, even if unregulated. "If it is common, it must be acceptable" (P1).

The third perspective is impoverishment. Poverty affects ethical judgements, in the sense that managers determine the morality of their political actions on basis of how they create or entrench poverty and marginalize or treat poor people. With limited social welfare services in Ghana to reduce abject poverty (Dankyi et al. 2017), the respondents mentioned that CPA could derail (at worst) or stifle (at best) government's efforts, policies and institutions to create and equitably distribute social benefits. In this respect, CPA is perceived to be unethical.

Because we try to connect with politicians in this country where there is high poverty, the default thinking is that we are doing something that will benefit ourselves and harm the others (P1)

Overall, these findings bring to the fore the impact of a country's regulatory, institutional and socio-economic conditions on ethical judgements of CPA. Though they may be consistent with other ethical issues expounded in the literature, some are different to an extent. For instance, previous studies have rarely explored beyond the effect of the organizational context on ethical issues. The findings herein capture ethical judgements based on the national context. Moreover, the impoverishment perspective is new to the literature. More importantly, the findings contradict Abratt et al.'s (1992) claim that culture does not play a role in managers' ethical beliefs. Their study of South African and Australian managers suggests that context does not matter in ethical analysis. This is contentious, considering the prevalence of institutional differences and moral relativism across the world. In advanced countries, fraud is widely understood to be unethical. In South Africa, Rossouw (2000) found that fraudsters rationalize their actions using the old alibi that "when in Rome, do what the Romans do". Surely, context matters in ethical judgements in Africa (Muthuri and Gilbert 2011).

\section{Organization Level}

At the organizational level, managers' ethical judgements are based on the firms or organizations doing CPA. Here, two criteria are used. The first is firm size. When large firms are involved in CPA, the perception is that the practice is unethical. Such perceptions are largely held by managers from small firms. The reason for this view is explicated on the grounds of fairness, with respondents arguing that large firms are already privileged and should not use the policy process for further enrichment to the detriment of smaller firms. This view is consistent with previous expositions of power abuse (e.g. Alzola 2013; Leong et al. 2013) and pseudo-voice (Barnett 2013). On the flipside, small firms are absolved of ethical responsibility, on the basis that they may not be able to use CPA to substantially harm competitors or society.

It's OK for small companies to try and do politics. In any case, we know they are mostly unsuccessful and their impact is less. They can have some of the national cake too, but we take exceptions to the large firms.

They have too much influence. (F2)

While such perceptions are aligned with the unequivocal fact that large firms do more CPA (e.g. Hillman et al. 2004; Lux et al. 2011), they are dangerous because they place small firms under the radar, even though they may be highly embedded in politics. They also overlook the possibility of politicians and their financiers using newly established (and small) companies as vehicles to formally extract rent from the State through fictitious or inflated contracts. More importantly, such perceptions, grounded in principles of fairness and equality, evince biases that could stifle innovation and entrepreneurship (Gao 2008). Large firms are not created overnight. They grow over time, through a combination of good management and competitive strategies. If they cannot reap the benefits of their success, such as political access, where is the motivation to grow? Clearly, this has implications for private sector development. Nevertheless, it is important to acknowledge that a large proportion of unethical practices in corporate Africa involve large firms, demonstrating the need for moral capitalism on the continent (Amaeshi and Idemudia 2015). A large firm manager noted:

Our competitors see our political engagements to be exploitative. They do not like that we have access to the political structure, but we have worked hard to gain the recognition and our impact on the economy is higher. If the politicians do not listen to us, it is bad for us and the country (I1)

The second criterion is organization type. Whether an organization is for-profit or non-profit influences the ethical perceptions of its CPA. The interviews revealed that managers hold a positive view of CPA by non-profit organizations (e.g. NGOs, charities), believing that these organizations uphold utilitarian values and work for the betterment of society. The opposite applies to profit organizations. By default, the CPA of these firms is perceived to be market distorting, selfinterested and unethical.

NGOs stand up for societies and communities. They are not selfish because they do not operate for money. We trust their political activity to be in the best interest of the country (V1) 
It is understandable why managers would hold positive evaluations of charities and NGOs in Ghana. These organizations have played an important role in the country's socioeconomic development (Porter 2003), manifested through their activities to strengthen institutions, structurally adjust the economy and reduce poverty (Gary 1996). However, not all NGO activity is ethical or utilitarian. According to Mercer (2002, p. 12), "NGO impact is more complex, serving to strengthen the state and/or society in some contexts, but to weaken or undermine them in others." In Ghana, there have been cases of NGO fraud (Duku-Boateng 2018), which should tamper the perceived "saintliness" of NGOs.

\section{Strategy Level}

The final level of analysis is the political strategy. Consistent with previous frameworks (Gao 2008; Tian et al. 2008; Weber 1997; Grimaldi 1998), I coded three distinct issues that managers consider to make ethical judgements-Purpose $(\mathrm{P})$, Mechanism $(\mathrm{M})$, and Outcome $(\mathrm{O})$. Respondents question the purpose $(\mathrm{P})$ of a political strategy to determine whether it is un/ethical. Three purposes emerged from the data. First, firms do CPA get public contracts or trade opportunities, similar to what happens in the Western world (e.g. Schuler et al. 2002; Witko 2011). Second, they do CPA for political support to overcome institutional weaknesses such as bureaucracy. Both purposes are self-interested, and are perceived to be unethical because they may disadvantage other firms. Nevertheless, they reflect the immense power politicians in developing countries wield to allocate resources and direct public machinery (Gao et al. 2017; Liedong and Frynas 2017; Peng and Luo 2000). The third purpose is to protect industry interests, which is perceived to be ethical, even if industry interests are not in consonance with public interests.

It is difficult to know what the public wants, because people have different positions. It becomes more convenient for us to think about what our associations and industry want, rather than what the public wants. (D1)

Managers noted the vagueness of public interests, indicating that there are always different views and positions on various issues, which makes it difficult to determine what the "public" is. "I cannot tell what the collective preference is, because different people want different things" (R1). In such situations, they consider their immediate group affiliations. This may explain why some communities in Africa overlook national interests to protect their members who are implicated in corruption. The cases of President Jacob Zuma of South Africa and Senator James Ibori of Nigeria's Delta State are examples where wrongdoing was defended by affiliated groups. Essentially, the "public" has a lesser meaning, and so do "public interests".
Managers also examine the ethicality of the mechanisms (M) through which the political strategies achieve the purposes of CPA. I coded two mechanisms from the datapolitical access and political capture. The political access mechanism exists when political strategies create opportunities for firms to reach politicians, be involved in political decisions or gain access to critical resources. Political access has been widely documented as an intermediate outcome or rationale of CPA (e.g. Ansolabehere et al. 2002; Liedong et al. 2015; Brown 2016; Mellahi et al. 2016). However, the political access mechanism herein has a much deeper connotation-it should not preclude or intentionally block others. In this sense, political access is ethical when firms focus on what they can get for themselves without stifling others. A fair playing field, similar to Oberman's (2004) political contestability argument, is central to this mechanism.

The opposite of political access is political capture, which refers to the process whereby firms use their CPA to prevent competitors or other stakeholders from gaining access to politicians or political systems. Firms that provide finance or logistics to political parties could wield power and control elected officials in ways that exclude others and destroy the quality and effectiveness of democratic institutions. Consistent with Abratt and Penman's (2002) findings in South Africa, I found that actions involving financial consideration or exchange are perceived to be unethical because they are exclusive. The political capture mechanism resembles firms using CPA to raise rivals' cost of doing business or control their competitors' access to resources in factor markets (e.g. Capron and Chatain 2008; McWilliams et al. 2002).

If you try to use your political engagements to get what you can get, your share of the national cake on the blind side of competitors, that's fine. When you stifle competitors, it's bad (U1)

The final criterion for analysing the ethicality of political strategies is the outcome $(\mathrm{O})$ of CPA. Does the cost exceed the benefit? Does CPA cause harm to others? Does it weaken national institutions? These questions underpin managers' judgements. CPA that generates more benefits than costs for firms, affiliated groups and the public (though difficult to determine), and does not undermine State institutions is perceived to be ethical. "For political engagements to be ethical, they must favour and support more people and systems than they destroy" (N1). This view reflects recent evidence of how business-government interactions cause corporate social irresponsibility, create dismal conditions and harm stakeholders in South Africa and Ghana (Hamann et al. 2019; Liedong and Rajwani 2018).

Based on the findings, I created an eclectic framework (Table 3) that reflects how managers make ethical judgements at the three levels (context, organization and strategy) using three ethical principles (utilitarianism, justice 
Table 3 Framework for ethical corporate political activity

\begin{tabular}{|c|c|c|c|}
\hline $\begin{array}{l}\text { Levels/principles } \\
\text { Context }\end{array}$ & $\begin{array}{l}\text { Principle of utilitarianism } \\
\text { Yes = ethical; No=ethical concern }\end{array}$ & $\begin{array}{l}\text { Principle of justice } \\
\text { Yes = ethical; } \text { No= ethical concern }\end{array}$ & $\begin{array}{l}\text { Principle of institutions } \\
\text { Yes = ethical; No= ethical concern }\end{array}$ \\
\hline Legality & $\begin{array}{l}\text { Is CPA regulated by law to benefit the } \\
\text { majority? }\end{array}$ & $\begin{array}{l}\text { Is CPA regulated by law to ensure equal } \\
\text { access to the polity? } \\
\text { Do CPA regulations prevent or reduce } \\
\text { harm done to other parties? } \\
\text { Do CPA regulations have provisions } \\
\text { to compensate affected or harmed } \\
\text { parties? }\end{array}$ & $\begin{array}{l}\text { Is CPA regulation effectively enforced? } \\
\text { Is CPA regulation regularly updated to } \\
\text { address weaknesses and account for } \\
\text { new developments? }\end{array}$ \\
\hline Legitimacy & $\begin{array}{l}\text { Is CPA accepted to be in the best inter- } \\
\text { est of the majority? } \\
\text { Is CPA expected and normal within the } \\
\text { political culture? }\end{array}$ & $\begin{array}{l}\text { Does CPA create or support a culture of } \\
\text { equality? } \\
\text { Is CPA practiced based on fairness? }\end{array}$ & $\begin{array}{l}\text { Does CPA strengthen State institutions? } \\
\text { Does CPA reduce existing institutional } \\
\text { weaknesses? }\end{array}$ \\
\hline Impoverishment & $\begin{array}{l}\text { Does CPA help to reduce poverty } \\
\text { among the masses? }\end{array}$ & $\begin{array}{l}\text { Is CPA fair to poor people, communities } \\
\text { and societies? } \\
\text { Does CPA allow the poor to have a } \\
\text { "voice"? }\end{array}$ & $\begin{array}{l}\text { Does CPA advocate, promote or support } \\
\text { policies and initiatives that will ensure } \\
\text { broad-based prosperity? }\end{array}$ \\
\hline Organization & Yes $=$ ethical concern $;$ No $=$ ethical & Yes $=$ ethical concern $;$ No $=$ ethical & Yes $=$ ethical concern $;$ No $=$ ethical \\
\hline Size & $\begin{array}{l}\text { Do large firms act in ways that harm the } \\
\text { majority? }\end{array}$ & $\begin{array}{l}\text { Do large firms reduce the representa- } \\
\text { tion or participation of other parties } \\
\text { in CPA }\end{array}$ & $\begin{array}{l}\text { Do large firms exploit institutional } \\
\text { weaknesses in their CPA? }\end{array}$ \\
\hline Type & $\begin{array}{l}\text { Is CPA done by profit-seeking organiza- } \\
\text { tions (serving their self-interests)? } \\
\text { Is CPA done by charities or non-gov- } \\
\text { ernmental organizations serving donor } \\
\text { interests? }\end{array}$ & $\begin{array}{l}\text { Is CPA done by profit-seeking organiza- } \\
\text { tions (seeking to silence opposing } \\
\text { voices)? }\end{array}$ & $\begin{array}{l}\text { Is CPA done by profit-seeking organiza- } \\
\text { tions (placing their interests over } \\
\text { institutional quality)? }\end{array}$ \\
\hline Strategy & Yes $=$ ethical concern $;$ No $=$ ethical & Yes $=$ ethical concern $;$ No $=$ ethical & Yes $=$ ethical concern $;$ No $=$ ethical \\
\hline Purpose & $\begin{array}{l}\text { Is CPA done to influence issues in } \\
\text { ways that favour a firm but harm the } \\
\text { majority? }\end{array}$ & $\begin{array}{l}\text { Is CPA done because the concerns of } \\
\text { other interest groups can be easily } \\
\text { overridden? }\end{array}$ & $\begin{array}{l}\text { Is CPA done because there is institutional } \\
\text { weakness to exploit? } \\
\text { Is CPA done to maintain a status quo of } \\
\text { intuitional weakness that allows easy } \\
\text { rent extraction and cronyism? }\end{array}$ \\
\hline Mechanism & $\begin{array}{l}\text { Is CPA done by marginalizing the } \\
\text { majority? } \\
\text { Is CPA done in a "winner takes all" } \\
\text { manner? } \\
\text { Are the gains of CPA achieved through } \\
\text { zero-sum means? }\end{array}$ & $\begin{array}{l}\text { Does CPA prevent other interest groups } \\
\text { from gaining access to politicians? } \\
\text { Does CPA exclude other parties from } \\
\text { democratic processes? } \\
\text { Does CPA discourage due process? }\end{array}$ & $\begin{array}{l}\text { Do politicians become captives or pup- } \\
\text { pets of the firms doing CPA? } \\
\text { Does CPA undermine democratic institu- } \\
\text { tions and processes? }\end{array}$ \\
\hline Outcomes & $\begin{array}{l}\text { Does CPA harm the majority? } \\
\text { Does CPA create or increase injury or } \\
\text { harm done to minority groups? }\end{array}$ & $\begin{array}{l}\text { Does CPA ignore harmed or injured } \\
\text { groups? } \\
\text { Are CPA outcomes unfair to other inter- } \\
\text { est groups? }\end{array}$ & $\begin{array}{l}\text { Does CPA weaken State institutions? } \\
\text { Does CPA increase poverty? }\end{array}$ \\
\hline
\end{tabular}

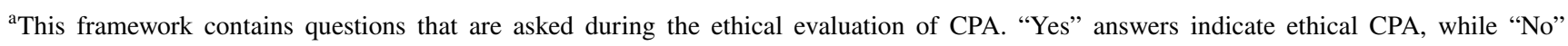
answers raise ethical concerns

and institutions). This framework, which contains the key questions asked during ethical evaluations, differs from previous works (e.g. Gao 2008; Oberman 2004; Tian et al. 2008 ) in two ways. First, it provides finer-grade multi-level criteria that is built on the "voice" and experience of ethical actors. Second, it considers the nuances and peculiar circumstances of CPA in weak institutional environments. As such, this framework has applicability in both developed and developing contexts. Leveraging the eclectic framework and respondents' first-hand accounts, I also create a model to show the process of ethical judgement. Personal experience (and intuition) and organizational experience interact to influence the ethical criteria managers use and the ethical principles they apply to make ethical judgements. These ethical judgements subsequently influence firms' CPA (i.e. the intensity and the strategies used) (Fig. 2). 


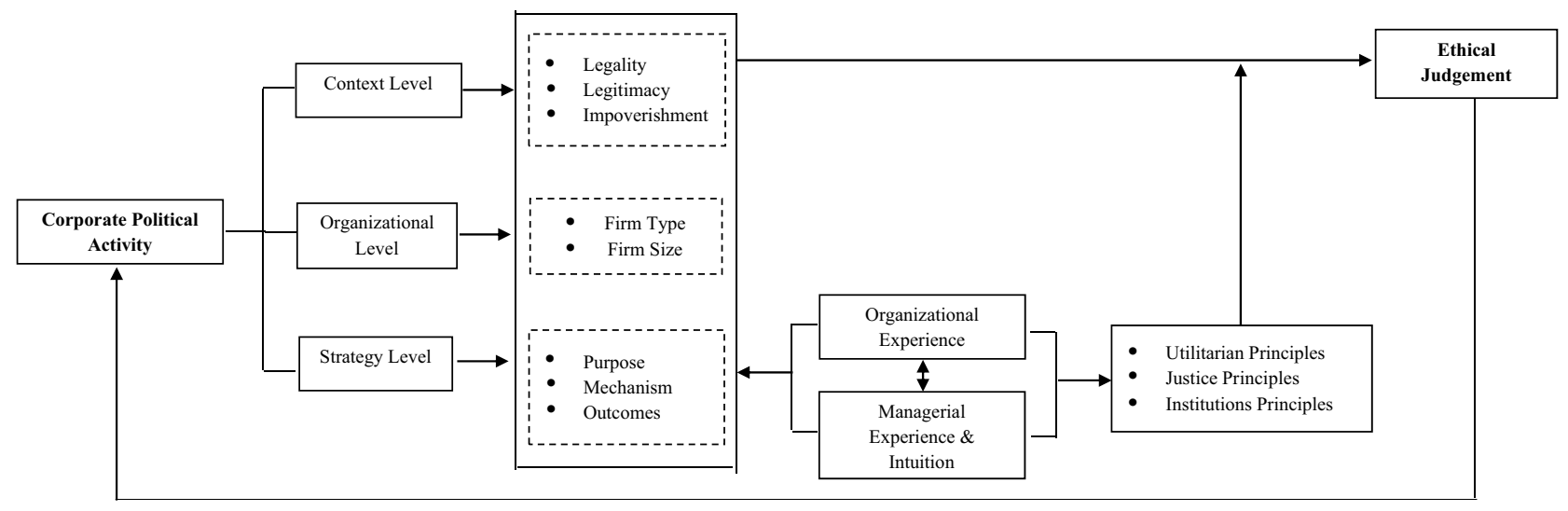

Fig. 2 Process model of ethical judgement

\section{Discussion and Conclusion}

In this article, I examined how managers evaluate the ethicality of CPA in weak institutional environments. The findings reveal that ethical judgements are made through an iterative discernment process using three ethical principles (i.e. utilitarianism, justice and institutions) at three levels (i.e. context, organizational and strategy). Consistent with the evidence, it is plausible to argue that CPA done in an appropriate context, by appropriate organizations and through appropriate channels is ethical. Appropriate, in this instance, refers to CPA that benefits the majority, treats other interest groups and firms equally and fairly, and supports or promotes institutional strengthening. The levels of ethical analysis reported in this article correspond with three crucial themes that have emerged from the data: (1) where CPA is done; (2) who does CPA; and (3) how CPA is done. These themes embody various criteria and principles that make significant contributions to the CPA and ethics literature. Before going into the contributions, I highlight a few pertinent issues that call to question the rationalist approach to CPA ethicality.

First, there is a strong view that the lack of CPA regulation makes corporate political engagements unethical. This view equates legality and ethicality, which of course is not appropriate as ethics should rise above law's minimum standards (Katz et al. 2017; Weber 1997), but it raises an interesting question-does the lack of specific CPA regulation make CPA unethical? According to Keffer and Hill (1997, p. 1376), "those actions that are legal and do not inflict undue harm on members of the community are categorized as good. Those activities that fall under the bad classification are considered illegal and have the potential to seriously injure parties outside of the lobbying process" Effectively, Keffer and Hill argue that legal lobbying is ethical lobbying, but is legality a good measure of ethicality? If yes, we would expect few or no ethical problems in countries such as US where CPA regulations exist. However, reality paints a different picture. Most ethical CPA frameworks and much of the critique in the literature are developed in response to lobbying in the US (e.g. Hamilton and Hoch 1997; Keffer and Hill 1997; Weber 1997; Neron 2016). In the emerging world, Brazil has campaign contribution laws but those laws could not prevent the political party financing scandals that were uncovered in the Operation Car Wash investigations.

The foregoing suggests that laws may not prevent unethical practices. Nevertheless, some managers in developing countries perceive legality as a measure of ethicality. Research in African countries show a strong focus on compliance-based ethics (e.g. Chilima 2019; Eweje 2009; Muthuri and Gilbert 2011; Nakpodia et al. 2018; Nwabuzor 2005; Price and Walt 2013), which demonstrates the importance of legislation in corporate governance and ethical judgements. Keffer and Hill's (1997) legal-ethics assertion resonates this reality in weak institutional contexts where CPA laws are non-existent. CPA regulations delineate boundaries of conduct, assign responsibilities and provide mechanisms for addressing political market failures. Without them, there are no standards for identifying wrongful behaviour and no basis to seek redress. In Ghana, the Political Parties Act (2000) has several loopholes (Arthur 2017), to an extent Fobih (2008) argues that party financing is unregulated except for a provision restricting foreign donations. Ghana also lacks a strong structure for lobbying or petitioning policy issues. The culmination of these institutional weaknesses is a nontransparent CPA environment that is prone to capture and clandestine dealings. In sum, laws provide a strong foundation for ethics but laws are not necessarily ethical. Moreover, even in the absence of CPA laws, all the respondents (including those holding the legality view) do CPA, which suggests the lack of rationality in CPA in weak institutional environments. 
Second, the perceived "saintliness" of charities' and NGOs' CPA requires scrutiny. Business and management researchers have not paid adequate attention to these organizations, as far as the ethicality of their CPA is concerned. NGO lobbying has been widely documented in the political and health sciences literature (e.g. Lencucha et al. 2011; Junk 2016; Warleigh 2000), but the morality of their political activity continues to fly under the radar, especially in developing countries where they are involved in public governance and social welfare provision. On the one hand, NGOs serve as the bridge between society and governments, representing the interests of communities in policy making. In Ghana, they have contributed to poverty reduction (Porter 2003) and the passing of various legislations (e.g. the Right to Information Law). In Tanzania, they have been involved in strengthening environmental and land policies (ElliottTeague 2008). In Kenya, they have drawn attention to supply chain issues and labour rights and helped to institutionalize CSR (Muthuri and Gilbert 2011). These activities paint a good picture of the work and role of NGOs in developing countries, but is this enough for a one-sided view that generalizes all NGO lobbying as ethical?

There is a dark side to NGO activity. Development has become big business with attractive financial benefits. In Ghana, and perhaps in other developing countries, there has been a proliferation of local NGOs over the past few decades. Not all of them are established to serve public interests. Some are vehicles for wealth accumulation, done through the embezzlement of grants. Others are vehicles for defrauding less privileged people (Duku-Boateng 2018). Even local politicians in Ghana create their own NGOs and use them as patronage structures and political vehicles for self and party promotion (Mohan 2002). These local NGO problems do not necessarily boost the saintliness of International NGOs whose operations also raise ethical concerns. There is a question of whether international NGOs are really committed to the development of poor countries. Anecdotal evidence suggests that executives of these organizations overlook, ignore or cover up misappropriation of developmental assistance due to fears that donors may cut back funding, which may cause them to lose their jobs (and the pecks). Hence, there is potential complicity of international NGOs in the widespread corruption recorded in developing countries.

Moreover, international NGOs may promote the interests or advance the agendas of their foreign donors or even act as their home governments' foreign policy vessels. This may not be in the best interest of developing countries. While they often collaborate with local NGOs to gain knowledge or legitimacy, the partnerships are not equal because they and their funders determine the policy agendas to a larger degree (Mohan 2002). In this sense for instance, the activities of USAID and DFID may support US and UK interests, but not those of the local people. Furthermore, there is the issue of power relations between international NGOs and governments in developing countries. These NGOs have the capacity to influence global politics and the policies of organizations on which developing countries are largely dependent, such as the World Bank, International Monetary Fund and United Nations (Tallberg et al. 2018). They may also receive strong backing from powerful home governments, dwarfing the ability of poor countries to withstand their political pressures. In sum, not all NGOs are saints and not all their CPA is ethical. However, due to bounded rationality and intuition, managers think otherwise.

Shifting to the significance of this article, I would like to first acknowledge that some studies have posited theoretical frameworks for examining the ethicality of CPA (e.g. Gao 2008; Weber 1997; Hamilton and Hoch 1997; Oberman 2004; Tian et al. 2008). However, these studies focus on the ethical requirements of political strategies. Therefore, they address only the third level of ethical analysis that I have presented in this article. What I add to these frameworks are 1) the contextual level to account for the impact of institutions and 2) the organizational level to capture the impact of firm characteristics in the ethical analysis of CPA. By adding these two new levels, I extend theory beyond extant criteria for judging the ethics of political activity. The findings seem to suggest that, just as firm and institutional-level factors influence political strategy formulation and mode of political engagement (Hillman and Keim 1995; Hillman and Hitt 1999; Barron 2011), so do they influence ethical judgements.

While some of the issues and ethical principles reported in this article consistently validate and lend credence to extant theoretical criteria, others mark a distant extension. Noteworthy is the institutions principle that has emerged as a lens for evaluating ethicality. Extant frameworks draw heavily on utilitarian, justice and rights theories of ethics (Bentham, 1789; Cavanaugh et al. 1981; Rawls 1971). Surprisingly, the latter was not recognized by the respondents, arguably because of a poor understanding of, and weak enforcement of the rule of law in Ghana. Instead, it was replaced by an institutions perspective bordering on institutional strengthening - a broader lens encapsulating rights, freedoms, structures and systems. This institutions perspective is arguably inconspicuous in Western-based ethics frameworks (e.g. Keffer and Hill 1997; Oberman 2004) but it echoes institutional failures in developing countries and how ethical judgements consider institutional strengthening as an important criterion.

I also present evidence that corroborate the weaknesses of the utilitarian and justice theories of ethics (see Gao 2008; Post et al. 1999). It is difficult for managers to determine "public interest" or measure the cost and benefits of their actions, which causes them to resort to intuitively using their impact on affiliated groups as the utilitarian yardstick 
regardless of the groups' representativeness. In this respect, utilitarian "consequentialism" (Mill 1863; Audi 2007) is narrowly interpreted in weak institutional environments. Due to weak and non-existent institutional structures, policy makers also struggle to determine the greatest good for the greatest number, causing them to intuitively and conveniently lean towards powerful interests with the loudest voice. This article shows that utilitarianism in weak institutional environments is based on "power-voice", not "cost-benefits." Consequently, small firms perceive the political engagements of large (i.e. powerful) firms to be unethical. This view reflects a sense of equal entitlement that casts negative light on firms using their competitive advantage and success as a basis for seeking differential or preferential treatment from the polity. Such views could de-motivate entrepreneurship and innovation (see Gao 2008).

Overall, the ethical framework I present in this article bridges the gap between theoretical frameworks and empirics to show how the ethicality of CPA is actually perceived and judged. Doing this, I move away from abstraction to reality, helping to open the "black box" to understand how managers make ethical judgements of CPA. I show that the determination of ethicality is a process underpinned by personal experiences and intuition, making it a subjective rather than a rational exercise. However, regardless of this subjectivity, the findings show that CPA is mostly perceived to be unethical in weak institutional environments. As such, this article helps to reveal how the dark side of CPA might manifest, and therefore contributes to the bourgeoning literature on the negative socio-economic and governance implications of CPA (e.g. Khwaja and Mian 2005; Liedong and Rajwani 2018; Mantere et al. 2009; Sun et al. 2016).

The dark side of CPA is particularly manifested through the strategies firms deploy. In Ghana, I found that political strategies are leveraged on absent and weak institutional conditions, but more importantly I observe that these strategies are means for developing managerial political tiesthe dominant strategies in emerging market CPA literature (Rajwani and Liedong 2015). In this sense, the financial, logistics and relational strategies are mere lower-order strategies that are used to develop and orchestrate higher-order strategies such as political ties. Based on this new learning, this article contributes to unpacking the mechanisms underlying managerial political ties.

\section{Practice Implications}

Besides theoretical contributions, this article has practical relevance. It provides lessons to help managers orchestrate ethical CPA. Firms must not only think about the ethicality of their political strategies, but must also consider the environment and the structure of the society where they operate. Recognition of institutional conditions will enable managers to develop CPA strategies while taking into consideration the likely perceptions and reactions of different stakeholders. The questions contained in the framework herein provide good guidance in that regard.

To address the difficulties of estimating the cost and benefits of their CPA, firms may consider creating or strengthening their public and government affairs departments or functions. Public affairs functions do not only provide a channel for firms to demonstrate transparency or a window for the public to see what goes in firms, but they are also vessels for collecting information and gauging public opinion (Griffin and Dunn 2004). In Ghana, research shows that they are useful for engaging stakeholders and legitimizing CSR (Liedong et al. 2017). They could thus be useful for engaging the public and conducting systematic assessments of policy issues, which will help to ensure that CPA is done in accordance with utilitarian principles. In addition, firms could re-structure their top management teams to place a stronger emphasis on external engagements. Board committees for public and government affairs could be used to achieve this. Alternatively, as recommended by Doh et al (2014), firms could use a dual-CEO management structure whereby they have Chief Executive Officers (CEO) responsible for market strategizing and Chief External Officers (CEO) for non-market strategizing. The latter could ensure proper evaluation of policy outcomes for the wider public.

Taking cue from the findings, governments in developing countries need to enact laws to regulate CPA. While these laws may exist, they either have loopholes or are poorly enforced, as in the case of Ghana (Arthur 2017; Ayee et al. 2008; Fobih 2011). Regulating CPA would make it possible to hold firms accountable for illegal and unethical political behaviour. It would also ensure transparency and reduce the incidence of bribery and corruption. Development agencies and NGOs should thus pay attention to CPA regulation, particular party financing, as this is a big source of the corruption and related developmental problems recorded in developing countries (Liedong 2017). In Ghana, this is very true (see Houlton 2012).

\section{Limitations and Future Research}

Despite this article making important theoretical and practical contributions, it has some limitations, which create avenues for future research. First, as seen in many qualitative studies, a small sample size limits generalizability. Future studies could therefore try to validate my ethical framework in other institutional contexts. Particularly, it would be insightful to investigate whether the institutions principle resonates in other developing countries.

Second, existing frameworks for ethical lobbying and the treatise of ethics in the business and management literature predominantly focus on the political activities of 
corporations (e.g. Gao 2008; Tian et al. 2008; Neron 2016) while relegating those of charities and NGOs to the background, suggesting an implicit assumption that the third sector's CPA is all ethical. As I have already specified elsewhere in this article, such assumptions are problematic. Future research should investigate, and preferably develop a lobbying framework for NGOs. They play an important role in public and global governance, and their activities have ethical implications.

Third, though a quantitative component could be added to this article to statistically tested the findings (i.e. mixed methods), such a component would require one or more separate in-depth studies to effectively address the scale of the opportunity. Accordingly, I suggest the following directions. Based on the framework herein, future research could quantitatively examine how personal and firm-level factors affect managers' perceptions of CPA ethicality. In doing this, survey and secondary data could be used to investigate the antecedents of the ethicality of different political strategies. Also, following previous works (e.g. Abratt et al. 1992; Abratt and Penman 2002), future research could use crossnational samples to statistically measure and compare the criteria for ethical judgement. This will increase understanding of how institutional and cultural variations affect ethical evaluation. Along this line, the scope could be extended to different interest groups (e.g. politicians, civil society), with specific focus on comparing convergences and divergences in how various stakeholders evaluate the ethicality of political engagements.

Further, the findings in this article may have implications for the CPA firm performance relationship. There is a plethora of research about the impact of political strategies on performance (e.g. Bliss and Gul 2012; Peng and Luo 2000; Guo et al. 2014), but there is limited knowledge of the mechanisms of this impact (Lux et al. 2011; Liedong and Rajwani 2018). Studies have shown how consumers respond to unethical corporate behaviours by adjusting their purchase behaviours (Miller and Sturdivant 1977; Deng 2012). Could ethicality mediate the value of CPA? This is an interesting research question worth answering in future quantitative research.

Funding This research received no specific grant from any funding agency in the public, commercial, or not-for-profit sectors.

\section{Compliance with Ethical Standards}

Conflict of interest The authors declare that they have no conflict of interest.

Ethical Approval All procedures performed in studies involving human participants were in accordance with the ethical standards of the insti- tutional and/or national research committee and with the 1964 Helsinki declaration and its later amendments or comparable ethical standards.

Informed consent Informed consent was obtained from all individual participants included in the study.

Open Access This article is licensed under a Creative Commons Attribution 4.0 International License, which permits use, sharing, adaptation, distribution and reproduction in any medium or format, as long as you give appropriate credit to the original author(s) and the source, provide a link to the Creative Commons licence, and indicate if changes were made. The images or other third party material in this article are included in the article's Creative Commons licence, unless indicated otherwise in a credit line to the material. If material is not included in the article's Creative Commons licence and your intended use is not permitted by statutory regulation or exceeds the permitted use, you will need to obtain permission directly from the copyright holder. To view a copy of this licence, visit http://creativecommons.org/licenses/by/4.0/.

\section{References}

Abratt, R., Nel, D., \& Higgs, N. S. (1992). An examination of the ethical beliefs of managers using selected scenarios in a crosscultural environment. Journal of Business Ethics, 11(1), 29-35.

Abratt, R., \& Penman, N. (2002). Understanding factors affecting salespeople's perceptions of ethical behavior in South Africa. Journal of Business Ethics, 35(4), 269-280.

Acquaah, M. (2007). Managerial social capital, strategic orientation, and organizational performance in an emerging economy. Strategic Management Journal, 28(12), 1235-1255.

Acquaah, M. (2012). Social networking relationships, firm-specific managerial experience and firm performance in a transition economy: A comparative analysis of family owned and nonfamily firms. Strategic Management Journal, 33(10), 1215-1228.

Allard, N. W. (2008). Lobbying is an honorable profession: The right to petition and the competition to be right. Stanford Law and Policy Review, 19, 23-68.

Alzola, M. (2013). Corporate dystopia: The ethics of corporate political spending. Business \& Society, 52(3), 388-426.

Amaeshi, K., Adegbite, E., \& Rajwani, T. (2016). Corporate social responsibility in challenging and non-enabling institutional contexts: Do institutional voids matter? Journal of Business Ethics, 134(1), 135-153.

Amankwah-Amoah, J., Debrah, Y. A., Honyenuga, B. Q., \& Adzoyi, P. N. (2018). Business and government interdependence in emerging economies: Insights from hotels in Ghana. International Journal of Tourism Research, 20(1), 72-81.

Ansolabehere, S., Snyder, J. M., Jr., \& Tripathi, M. (2002). Are PAC contributions and lobbying linked? New evidence from the 1995 lobby disclosure act. Business \& Politics, 4(2), 131-155.

Arthur, P. (2017). Political parties' campaign financing in Ghana's fourth republic: A contribution to the discourse. Journal of Asian and African Studies, 52(8), 1124-1140.

Atta Mills, C. (2018). Politics, policy, and implementation: The 'Ghanaian Paradox. Retrieved from: https://www.brookings.edu/blog/ africa-in-focus/2018/07/18/politics-policy-and-implementationthe-ghanaian-paradox/.

Audi, R. (2007). Can utilitarianism be distributive? Maximization and distribution as criteria in managerial decisions. Business Ethics Quarterly, 17(4), 593-611.

Ayee, J., Anebo, F., \& Debrah, E. (2008). Financing political parties in Ghana. Dakar: The Consortium for Development. 
Ayentimi, D. T., Burgess, J., \& Brown, K. (2018). HRM practices of MNEs and domestic firms in Ghana: Divergence or convergence? Personnel Review, 47(1), 2-21.

Bagbin, A. S. K., \& Ahenkan, A. (2017). Political party financing and reporting in Ghana: Practitioner perspectives. In K. Mensah (Ed.), Political marketing and management in Ghana (pp. 111-131). London: Palgrave Macmillan.

Bargh, J., \& Chartrand, T. (1999). The unbearable automaticity of being. American Psychologist, 54, 462-479.

Barker, D. (2008). Ethics and lobbying: The case of real estate brokerage. Journal of Business Ethics, 80(1), 23-35.

Barnett, M. L. (2013). One voice, but whose voice? Exploring what drives trade association activity. Business \& Society, 52(2), 213-244.

Barraquier, A. (2011). Ethical behaviour in practice: Decision outcomes and strategic implications. British Journal of Management, 22, S28-S46.

Barron, A. (2011). Exploring national culture's consequences on international business lobbying. Journal of World Business, 46(3), 320-327.

Bauer, T. (2014). Responsible lobbying. Journal of Corporate Citizenship, 53, 61-76.

Beddewela, E., \& Fairbrass, J. (2016). Seeking legitimacy through CSR: Institutional pressures and corporate responses of multinationals in Sri Lanka. Journal of Business Ethics, 136(3), 503-522.

Bentham, J. (1789). An introduction to the principles of morals and legislation. New York: Hafner.

Bliss, M. A., \& Gul, F. A. (2012). Political connection and cost of debt: Some Malaysian evidence. Journal of Banking \& Finance, 36(5), 1520-1527.

Bonardi, J. P., Holburn, G. L. F., \& Bergh, R. G. V. (2006). Nonmarket strategy performance: Evidence from U.S. electric utilities. Academy of Management Journal, 49(6), 1209-1228.

Bonardi, J. P., Hillman, A. J., \& Keim, G. D. (2005). The attractiveness of political markets: Implications for firm strategy. Academy of Management Review, 30(2), 397-413.

Brown, R. S. (2016). How do firms compete in the non-market? The process of political capability building. Business \& Politics, 18(3), 263-295.

Capron, L., \& Chatain, O. (2008). Competitors' resource-oriented strategies: Acting on competitors' resources through interventions in factor markets and political markets. Academy of Management Review, 33(1), 97-121.

Carretta, A., Farina, V., Gon, A., \& Parisi, A. (2012). Politicians 'on board': Do political connections affect banking activities in Italy? European Management Review, 9(2), 75-83.

Cavanaugh, G. F., Moberg, D. J., \& Velasquez, M. (1981). The ethics of organizational politics. Academy of Management Review, 6(3), 363-374.

Ghana, C. D. D. (2018). The cost of politics in Ghana. Accra: CDD Ghana.

Chilima, S. K. (2019). Addressing moral decadence: Towards an effective compliance and ethics program. Africa Journal of Management, 5(1), 98-111.

Christensen, S. L. (1997). The new federalism: Implications for the legitimacy of corporate political activity. Business Ethics Quarterly, 7(3), 81-91.

Christensen, D. M., Mikhail, M. B., Walther, B. R., \& Wellman, L. A. (2017). From K Street to Wall Street: Political connections and stock recommendations. The Accounting Review, 92(3), 87-112.

Claessens, S., Feijen, E., \& Laeven, L. (2008). Political connections and preferential access to finance: The role of campaign contributions. Journal of Financial Economics, 88(3), 554-580.
Clawson, D., Neustadtl, A., \& Weller, M. (1998). Dollars and votes: How business campaign contributions subvert democracy. Philadelphia: Temple University Press.

Cooper, M. J., Gulen, H., \& Ovtchinnikov, A. V. (2010). Corporate political contributions and stock returns. Journal of Finance, 65(2), 687-724.

Corbin, J., \& Strauss, A. (1990). Grounded theory research: Procedures, canons, and evaluative criteria. Qualitative Sociology, 13(1), 3-21.

Dankyi, E., Mazzucato, V., \& Manuh, T. (2017). Reciprocity in global social protection: Providing care for migrants' children. Oxford Development Studies, 45(1), 80-95.

De Cremer, D., van Dick, R., Tenbrunsel, A., Pillutla, M., \& Murnighan, J. K. (2011). Understanding ethical behavior and decision making in management: A behavioural business ethics approach. British Journal of Management, 22, S1-S4.

Dean, T., Vryza, M., \& Fryxell, G. E. (1998). Do corporate PACs restrict competition? An empirical examination of industry PAC contributions and entry. Business and Society, 37(2), 135-156.

Debrah, Y. A. (2002). Ghana. Thunderbird. International Business Review, 44(4), 495-513.

Decker, S. (2011). Corporate political activity in less developed countries: The volta river project in Ghana, 1958-66. Business History, 53(7), 993-1017.

Deng, X. (2012). Understanding consumer's responses to enterprise's ethical behaviors: An investigation in china. Journal of Business Ethics, 107(2), 159-181.

Doh, J., Lawton, T., Rajwani, T., \& Paroutis, S. (2014). Why your company may need a chief external officer: Upgrading external affairs can help align strategy and improve competitive advantage. Organization Dynamics, 43(2), 96-104.

Duku-Boateng, F. (2018). PWDs defrauded by NGO appeal for IGP's intervention. Retrieved from www.ghananewsagency.org/social/ pwds-defrauded-by-ngo-appeal-for-igp-s-intervention-146342.

Dworkin, R. (2000). Sovereign virtue. Cambridge, MA: Harvard Business Press.

Eisenhardt, K. M. (1989). Building theories from case study research. Academy of Management Review, 14(4), 532-550.

Eweje, G. (2009). Labour relations and ethical dilemmas of extractive MNEs in Nigeria, South Africa and Zambia: 1950-2000. Journal of Business Ethics, 86, 207-223.

Elliott-Teague, G. (2008). Coalition lobbying in Tanzania: The experiences of local NGOs. Journal of Public Affairs, 8(1), 99-114.

Faccio, M. (2006). Politically connected firms. American Economic Review, 96(1), 369-386.

Fobih, N. (2008). Political parties and democratic development in Ghana: From transition to consolidation and beyond. (Unpublished $\mathrm{PhD}$ ). Queen's University, Kingston, Canada.

Fobih, N. (2011). Challenges to party development and democratic consolidation: Perspectives on reforming Ghana's institutional framework. Journal of Asian and African Studies, 46(6), $578-592$.

Fuller, J. B., Hester, K., Barnett, T., Frey, L., Relyea, C., \& Beu, D. (2006). Perceived external prestige and internal respect: New insights into the organizational identification process. Human Relations, 59(6), 815-846.

Gao, Y. (2008). An ethical judgment framework for corporate political actions. Journal of Public Affairs, 8(3), 153-163.

Gao, Y., Shu, C., Jiang, X., Gao, S., \& Page, A. L. (2017). Managerial ties and product innovation: The moderating roles of macro- and micro-institutional environments. Long Range Planning, 50(2), $168-183$.

Gary, I. (1996). Confrontation, co-operation or co-optation: NGOs and the Ghanaian state during structural. Review of African Political Economy, 23(68), 149-163. 
Getz, K. A. (1997). Research in corporate political action. Business \& Society, 36(1), 32-72.

Gioia, D. A., Corley, K. G., \& Hamilton, A. L. (2013). Seeking qualitative rigor in inductive research: Notes on the Gioia methodology. Organizational Research Methods, 16(1), 15-31.

Griffin, J. J., \& Dunn, P. (2004). Corporate public affairs: Commitment, resources, and structure. Business \& Society, 43(2), 196-220.

Grimaldi, J. (1998). Ethics and the political activities of US business. Business Ethics: A European Review, 7(4), 250-249.

Guo, H., Xu, E. M., \& Jacobs, M. (2014). Managerial political ties and firm performance during institutional transitions: An analysis of mediating mechanisms. Journal of Business Research, 67(2), $116-127$.

Hadani, M., \& Schuler, D. A. (2013). In search of El Dorado: The elusive financial returns on corporate political investments. Strategic Management Journal, 34(2), 165-181.

Haidt, J. (2001). The emotional dog and its rational tail: A social intuitionist approach to moral judgment. Psychological Review, 108(4), 814-834.

Hamann, R., Kourula, A., Moon, J., Salles-Djelic, M., \& Wickert, C. (2019). Dynamic de-responsibilization in business-Government interactions. Organization Studies, 40(8), 1193-1215.

Hamilton, B., \& Hoch, D. (1997). Ethical standards for business lobbying: Some practical suggestions. Business Ethics Quarterly, 7(3), 117-129.

Henisz, W. J. (2004). Political institutions and policy volatility. Economics \& Politics, 16(1), 1-27.

Henisz, W. J., \& Zelner, B. A. (2010). The hidden risks in emerging markets. Harvard Business Review, 88(4), 88-95.

Hennchen, E. (2015). Royal Dutch shell in Nigeria: Where do responsibilities end? Journal of Business Ethics, 129(1), 1-25.

Hilliard, V. G. (2002). Beyond the Confines of Compliance and Virtue: Honing a Set of Global Ethics for South Africa and the United States of America. Public Administration Quarterly, 25(4), 436-446.

Hillman, A. J., \& Hitt, M. A. (1999). Corporate political strategy formulation: A model of approach, participation, and strategy decisions. Academy of Management Review, 24(4), 825-842.

Hillman, A. J., \& Wan, W. P. (2005). The determinants of MNE subsidiaries' political strategies: Evidence of institutional duality. Journal of International Business Studies, 36(3), 322-340.

Hillman, A. J., Withers, M. C., \& Collins, B. J. (2009). Resource dependence theory: A review. Journal of Management, 35(6), $1404-1427$.

Hillman, A., \& Keim, G. (1995). International variation in the business-government interface: Institutional and organizational considerations. Academy of Management Review, 20(1), 193-214.

Hillman, A. J., Keim, G. D., \& Schuler, D. (2004). Corporate political activity: A review and research agenda. Journal of Management, $30(6), 837-857$.

Houlton, S. (2012). Ghanaian government financier faces corruption charges. Retrieved from https://www.dw.com/en/ghanaian-gover nment-financier-faces-corruption-charges/a-15741964.

Hunt, S. D., \& Vitell, S. (1986). A general theory of marketing ethics. Journal of Macromarketing, 6(1), 5-16.

Johnson, S., \& Mitton, T. (2003). Cronyism and capital controls: Evidence from Malaysia. Journal of Financial Economics, 67(2), 351-382.

Jones, T. M. (1991). Ethical decision making by individuals in organizations: An issue-contingent model. Academy of Management Review, 16(2), 366-395.

Junk, W. M. (2016). Two logics of NGO advocacy: Understanding inside and outside lobbying on EU environmental policies. Journal of European Public Policy, 23(2), 236-254.

Katz, M., Lopez, Y. P., \& LaVan, H. (2017). Domestic violence spillover into the workplace: An examination of the difference between legal and ethical requirements. Business \& Society Review, 122(4), 557-587.

Keffer, J. M., \& Hill, R. P. (1997). An ethical approach to lobbying activities of businesses in the United States. Journal of Business Ethics, 16(12), 1371-1379.

Keim, G. D., \& Zeithaml, V. A. (1981). Improving the return on advocacy advertising. Financial Executive, 49(11), 40-44.

Keim, G. D., \& Zeithaml, C. P. (1986). Corporate political strategy and legislative decision making: A review and contingency approach. Academy of Management Review, 11(4), 828-843.

Kelley, P. C., \& Elm, D. R. (2003). The effect of context on moral intensity of ethical issues: Revising jones's issue-contingent model. Journal of Business Ethics, 48(2), 139-154.

Khwaja, A. I., \& Mian, A. (2005). Do lenders favour politically connected firms? Rent provision in an emerging financial market. Quarterly Journal of Economics, 120(4), 1371-1411.

Langley, A. (1999). Strategies for theorizing from process data. Academy of Management Review, 24(4), 691-710.

Lascelles, D. (2005). The ethics of influence: Political donations and lobbying. London: Institute of Business Ethics.

Lawton, T., McGuire, S., \& Rajwani, T. (2013). Corporate political activity: A literature review and research agenda. International Journal of Management Reviews, 15(1), 86-105.

Lawton, T. C., Doh, J. P., \& Rajwani, T. (2014). Aligning for advantage. Oxford, England: Oxford University Press.

Lencucha, R., Kothari, A., \& Labonté, R. (2011). The role of nongovernmental organizations in global health diplomacy: Negotiating the framework convention on tobacco control. Health Policy \& Planning, 26(5), 405-412.

Leong, S., Hazelton, J., \& Townley, C. (2013). Managing the risks of corporate political donations: A utilitarian perspective. Journal of Business Ethics, 118(2), 429-445.

Lester, R. H., Hillman, A., Zardkoohi, A., \& Cannella, A. A., Jr. (2008). Former government officials as outside directors: The role of human and social capital. Academy of Management Journal, 51(5), 999-1013.

Li, H., \& Zhang, Y. (2007). The role of managers' political networking and functional experience in new venture performance: Evidence from china's transition economy. Strategic Management Journal, 28(8), 791-804.

Li, J. J., Poppo, L., \& Zhou, K. Z. (2008). Do managerial ties in china always produce value? Competition, uncertainty, and domestic vs. foreign firms. Strategic Management Journal, 29(4), 383-400.

Liedong, T. A., \& Frynas, G. J. (2017). Investment climate constraints as determinants of political tie intensity in emerging countries: Evidence from foreign firms in Ghana. Management International Review, 58(5), 675-703.

Liedong, T. A. (2017). Combating corruption in Africa through institutional entrepreneurship: Peering in from businessgovernment relations. Africa Journal of Management, 3(3-4), 310-327.

Liedong, T. A., \& Rajwani, T. (2018). The impact of managerial political ties on corporate governance and debt financing: Evidence from Ghana. Long Range Planning, 51(5), 666-679.

Liedong, T. A., Ghobadian, A., Rajwani, T., \& O'Regan, N. (2015). Toward a view of complementarity: Trust and policy influence effects of corporate social responsibility and corporate political activity. Group \& Organization Management, 40(3), 405-427.

Liedong, T. A., Rajwani, T., \& Mellahi, K. (2017). Reality or illusion? The efficacy of nonmarket strategy in institutional risk reduction. British Journal of Management, 28(4), 609-628.

Logsdon, J. M. (2004). Global business citizenship: Applications to environmental issues. Business \& Society Review, 109(1), 67-87.

Lohmann, S. (1995). Information, access, and contributions: A signaling model of lobbying. Public Choice, 85(3-4), 267-284. 
Luiz, J., \& Stewart, C. (2014). Corruption, South African multinational enterprises and institutions in Africa. Journal of Business Ethics, 124(3), 383-398.

Lux, S., Crook, T. R., \& Woehr, D. J. (2011). Mixing business with politics: A meta-analysis of the antecedents and outcomes of corporate political activity. Journal of Management, 37(1), 223-247.

Magolowondo, A., Falguera, E., \& Matsimbe, Z. (2012). Regulating political party financing: Some insights from the praxis. Stockholm: International Institute for Democracy and Electoral Assistance.

Mantere, S., Pajunen, K., \& Lamberg, J. (2009). Vices and virtues of corporate political activity: The challenge of international business. Business \& Society, 48(1), 105-132.

Marsh, S. (1998). Creating barriers for foreign competitors: A study of the impact of anti-dumping actions on the performance of US firms. Strategic Management Journal, 19(1), 25-37.

Matten, D., \& Crane, A. (2005). Corporate citizenship: Toward an extended theoretical conceptualization. Academy of Management Review, 30(1), 166-179.

Mbalyohere, C., Lawton, T., Boojihawon, R., \& Viney, H. (2017). Corporate political activity and location-based advantage: MNE responses to institutional transformation in Uganda's electricity industry. Journal of World Business, 52(6), 743-759.

McWilliams, A., van Fleet, D. D., \& Cory, K. D. (2002). Raising rivals' costs through political strategy: An extension of resource-based theory. Journal of Management Studies, 39(5), 707-723.

Mellahi, K., Frynas, J. G., Sun, P., \& Siegel, D. (2016). A review of the nonmarket strategy literature: Toward a multi-theoretical integration. Journal of Management, 42(1), 143-173.

Mercer, C. (2002). NGOs, civil society and democratization: A critical review of the literature. Progress in Development Studies, 2(1), 5-22.

Mill, J. S. (1863). Utilitarianism. Indianapolis: Bobbs-Merill.

Miller, K. E., \& Sturdivant, F. D. (1977). Consumer responses to socially questionable corporate behavior: An empirical test. Journal of Consumer Research, 4(1), 1-7.

Milyo, J., Primo, D., \& Groseclose, T. (2000). Corporate PAC campaign contributions in perspective. Business \& Politics, 2(1), $75-88$.

Mitnick, B. M. (1993). Political contestability. In B. M. Mitnick (Ed.), Corporate political agency: The construction of competition in public affairs. Newbury Park, CA: Sage.

Mohan, G. (2002). The disappointment of civil society: The politics of NGO intervention in Ghana. Political Geography, 21(1), $125-154$.

Moon, J., Crane, A., \& Matten, D. (2005). Can corporations be citizens? Corporate citizenship as a metaphor for business participation in society. Business Ethics Quarterly, 15(3), 429-453.

Mordy, J. T. (2018). Afriyie ankrah confesses: Our hands are tied; we can't punish our funders. Retrieved from https://www.myjoy online.com/politics/2018/October-3rd/afriyie-ankrahs-confession -our-hands-are-tied-we-cant-punish-our-funders.php.

Morrison, L., Wilmshurst, T., \& Shimeld, S. (2018). Environmental reporting through an ethical looking glass. Journal of Business Ethics, 150(4), 903-918.

Morse, J. M., \& Richards, L. (2002). Readme first for a user's guide to qualitative methods. Thousand Oaks, CA: Sage.

Muthuri, J., \& Gilbert, V. (2011). An institutional analysis of corporate social responsibility in Kenya. Journal of Business Ethics, 98(3), 467-483.

Nakpodia, F., Adegbite, E., Amaeshi, K., \& Owolabi, A. (2018). Neither principles nor rules: Making corporate governance work in sub-Saharan Africa. Journal of Business Ethics, 151(2), 391-408.
Nell, P. C., Puck, J., \& Heidenreich, S. (2015). Strictly limited choice or agency? Institutional duality, legitimacy, and subsidiaries' political strategies. Journal of World Business, 50(2), 302-311.

Neron, P. Y. (2016). Rethinking the ethics of corporate political activities in a post-citizens united era: Political equality, corporate citizenship, and market failures. Journal of Business Ethics, 136(4), 715-728.

Neron, P. Y., \& Norman, W. (2008). Citizenship Inc: Do we really want businesses to be good corporate citizens? Business Ethics Quarterly, 18(1), 1-26.

North, D. C. (1990). Institutions, institutional change and economic performance. Cambridge: Cambridge University Press.

Nwabuzor, A. (2005). Corruption and development: New initiatives in economic openness and strengthened rule of law. Journal of Business Ethics, 59(1), 121-138.

Oberman, W. D. (2004). A framework for the ethical analysis of corporate political activity. Business \& Society Review, 109(2), 245-262.

Ostas, D. T. (2007). The law and ethics of K street. Business Ethics Quarterly, 17(1), 33-63.

Park, S. H., \& Luo, Y. (2001). Guanxi and organizational dynamics: Organizational networking in Chinese firms. Strategic Management Journal, 22(5), 455-477.

Peng, M. W., \& Luo, Y. (2000). Managerial ties and firm performance in a transition economy: The nature of a micro-macro link. Academy of Management Journal, 43(3), 486-501.

Perelman, C. (1963). The idea of justice and the problem of argument. New York: Humanities Press.

Porter, G. (2003). NGOs and poverty reduction in a globalizing world: Perspectives from Ghana. Progress in Development Studies, 3(2), 131-145.

Post, J. E., Lawrence, A. T., \& Weber, J. (1999). Business and society: Corporate strategy, public policy, ethics (10th ed.). New York: McGraw-Hill.

Puck, J. F., Rogers, H., \& Mohr, A. T. (2013). Flying under the radar: Foreign firm visibility and the efficacy of political strategies in emerging economies. International Business Review, 22(6), 1021-1033.

Price, G., \& Walt, A. (2013). Changes in attitudes towards business ethics held by former South African business management students. Journal of Business Ethics, 113(3), 429-440.

Rajwani, T., \& Liedong, T. A. (2015). Political activity and firm performance within nonmarket research: A review and international comparative assessment. Journal of World Business, 50(2), 273-283.

Rawls, J. (1971). A theory of justice. Cambridge, MA: Belknap Press.

Redish, M. H. (1982). The value of free speech. University of Pennsylvania Law Review, 130, 591-645.

Reinecke, J., Arnold, D. G., \& Palazzo, G. (2016). Qualitative methods in business ethics, corporate responsibility, and sustainability research. Business Ethics Quarterly, 26(4), xiii-xxii.

Rest, J. R. (1986). Moral development: Advances in research and theory. New York: Praeger.

Rossouw, G. J. (2000). Defining and understanding fraud: A South african case study. Business Ethics Quarterly, 10(4), 885-895.

Scherer, A. G., Baumann-Pauly, D., \& Schneider, A. (2013). Democratizing corporate governance: Compensating for the democratic deficit of corporate political activity and corporate citizenship. Business \& Society, 52(3), 473-514.

Schuler, D. A., Schnietz, K. E., \& Baggett, L. S. (2002). Determinants of foreign trade mission participation: An analysis of corporate political and trade activities. Business \& Society, 41(1), 6-35.

Sheng, S., Zhou, K. Z., \& Li, J. J. (2011). The effects of business and political ties on firm performance: Evidence from china. Journal of Marketing, 75(1), 1-15. 
Simon, H. A. (1972). Theories of bounded rationality. In C. B. McGure \& R. Radner (Eds.), Decision and organization (pp. 161-176). Amsterdam: North-Holland.

Strauss, A. L., \& Corbin, J. (1998). Basics of qualitative research: Techniques and procedures for developing grounded theory (2nd ed.). London: Sage. Retrieved from https:// search.ebscohost.com/login.aspx ?direct $=$ true $\& d b=$ cat 00 $164 \mathrm{a} \& \mathrm{AN}=$ cran $.376638 \&$ site $=$ eds-live.

Sun, P., Hu, H. W., \& Hillman, A. J. (2016). The dark side of board political capital: Enabling blockholder rent appropriation. Academy of Management Journal, 59(5), 1801-1822.

Tallberg, J., Dellmuth, L. M., Agné, H., \& Duit, A. (2018). NGO influence in international organizations: Information, access and exchange. British Journal of Political Science, 48(1), 213-238.

Tian, Z., Gao, H., \& Cone, M. (2008). A study of the ethical issues of private entrepreneurs participating in politics in china. Journal of Business Ethics, 80(3), 627-642.

Trevino, L. K. (1986). Ethical decision making in organizations: A person-situation interactionist model. Academy of Management Review, 11(3), 601-617.

Tsamenyi, M., Enninful-Adu, E., \& Onumah, J. (2007). Disclosure and corporate governance in developing countries: Evidence from Ghana. Managerial Auditing Journal, 22(3), 319-334.

van den Bersselaar, D., \& Decker, S. (2011). 'No longer at ease': Corruption as an institution in West Africa. International Journal of Public Administration, 34(11), 741-752.

Wan, W. P., \& Hillman, A. J. (2006). One of these things is not like the others: What contributes to dissimilarity among MNE subsidiaries' political strategy? Management International Review, $46,85-107$.

Wang, H., \& Qian, C. (2011). Corporate philanthropy and corporate financial performance: The roles of stakeholder response and political access. Academy of Management Journal, 54(6), $1159-1181$.

Warleigh, A. (2000). The hustle: Citizenship practice, NGOs and 'policy coalitions' in the European Union-The cases of auto oil, drinking water and unit pricing. Journal of European Public Policy, 7(2), 229-243.
Weaver, G. R. (2001). Ethics programs in global businesses: Culture's role in managing ethics. Journal of Business Ethics, 30(1), 3-15.

Weber, L. J. (1997). Ethics and the political activity of business: Reviewing the agenda. Business Ethics Quarterly, 7(3), 71-79.

Weidenbaum, M. L. (1980). Public policy: No longer a spectator sport for business. Journal of Business Strategy, 1(1), 46-53.

Weymouth, S. (2012). Firm lobbying and influence in developing countries: A multilevel approach. Business \& Politics, 14(4), 1-26.

White, G. O., Boddewyn, J. J., \& Galang, R. M. N. (2015). Legal system contingencies as determinants of political tie intensity by wholly owned foreign subsidiaries: Insights from the Philippines. Journal of World Business, 50(2), 342-356.

Witko, C. (2011). Campaign contributions, access, and government contracting. Journal of Public Administration Research and Theory, 21(4), 761-778.

Wocke, A., \& Moodley, T. (2015). Corporate political strategy and liability of foreignness: Similarities and differences between local and foreign firms in the South African health sector. International Business Review, 24(4), 700-709.

Wood, D. J., \& Logsdon, J. M. (2008). Business citizenship as metaphor and reality. Business Ethics Quarterly, 18(1), 51-59.

World Bank. (2005). Ghana corporate governance country assessment. Washington DC: World Bank.

Xin, K. K., \& Pearce, J. L. (1996). Guanxi: Connections as substitutes for formal institutional support. Academy of Management Journal, 39(6), 1641-1658. https://doi.org/10.2307/257072.

Yin, R. K. (2003). Building theories from case study research (5th ed.). Thousand Oaks, CA: Sage.

Zhao, M. (2012). CSR-based political legitimacy strategy: Managing the state by doing good in China and Russia. Journal of Business Ethics, 111(4), 439-460.

Publisher's Note Springer Nature remains neutral with regard to jurisdictional claims in published maps and institutional affiliations. 